\title{
Natural radioactivity in rocks of the Modane-Aussois region (SE France)
}

\author{
Dariusz Malczewski • Jerzy $\dot{Z}$ aba
}

Received: 26 July 2011 / Published online: 20 September 2011

(c) The Author(s) 2011. This article is published with open access at Springerlink.com

\begin{abstract}
The activity concentrations of ${ }^{40} \mathrm{~K},{ }^{232} \mathrm{Th}$, and ${ }^{238} \mathrm{U}$ in the characteristic rocks of the Modane-Aussois region (Western Alps, France) were determined using an HPGe gamma-ray spectrometry system. The activity concentrations of ${ }^{40} \mathrm{~K}$ varied from $18 \mathrm{Bqkg}^{-1}$ (limestone dolomite) to $392 \mathrm{Bqkg}^{-1}$ (calcschist), while those of ${ }^{232} \mathrm{Th}$ varied from $0.7 \mathrm{Bqkg}^{-1}$ (limestone dolomite) to $18 \mathrm{Bqkg}^{-1}$ (calcschist). The activities associated with ${ }^{238} \mathrm{U}$ ranged from 9 (quartzite) to $29 \mathrm{Bqkg}^{-1}$ (dolomite). In the investigated rock samples, concentrations of ${ }^{238} \mathrm{U}(\mathrm{ppm})$ and ${ }^{40} \mathrm{~K}(\%)$ had a strong negative correlation.
\end{abstract}

Keywords Carbonate rocks - Quartzite - Potassium-40 . Uranium · Thorium

\section{Introduction}

In 2006, the activities of naturally occurring radionuclides in the characteristic rocks of the Modane-Aussois region were measured to compare them with gamma-ray background measurements from the Laboratoire Souterrain de Modane (LSM) within the ILIAS (Integrated Large Infrastructures for Astroparticle Physics) project. The LSM is located in the Frejus highway tunnel connecting Italy and France $1200 \mathrm{~m}$ a.s.1. During that time, LSM's main

D. Malczewski $(\bowtie) \cdot$ J. Żaba

Faculty of Earth Sciences, University of Silesia, Będzińska 60, 41-200 Sosnowiec, Poland

e-mail: dariusz.malczewski@us.edu.pl

J. Żaba

e-mail: jerzy.zaba@us.edu.pl scientific program included dark matter detection and the neutrinoless double beta decay experiment (NEMO).

\section{Geological setting}

The investigated area belongs to the Aussois-Modane region in the French portion of the Western Alps, which is close to the "de Frejus" tunnel entrance connecting the French Modane with the Italian Bardonecchia. Its terrain is situated in the internal arc of the Western Alps formed by an internal zone of the Penninic nappes. The following tectonic units are distinguishable (from inner to outer): the Briançonnais, Subbriançonnais, Valaisan, Cheval Noir flysch (Penninc units), and Dauphinois domains (Fig. 1). A major tectonic boundary separates the Penninic units from the Dauphinois domain. This boundary is called the Pennine/Penninic Front [1-4], and is also referred to as the Pennine/Penninic Frontal Thrust [5-9], the Penninic Basal Contact [10, 11], and the Basal Penninic Fault [12]. In the past this thrust represented a suture zone between the Dauphinois and Briançonnais/Subbriançonnais units that was active during the Eocene period [13]. During the second deformation stage (Oligo-Miocene), the Roselend Thrust (Fig. 1) completely reworked the Penninic Front.

In the French-Italian Western Alps, the internal arc originated from an oceanic accretionary wedge, which was incorporated in a wider orogenic wedge during the Paleogene collision [9, 14]. During the Neogene, this arc was subjected to widespread ductile to brittle extension.

The Aussois-Modane region is located in the Briançonnais unit (Middle Penninic [10, 15]. This area is characterized by a very complicated tectonic structure. Basically, the main units are the stratigraphic series from the Lower 


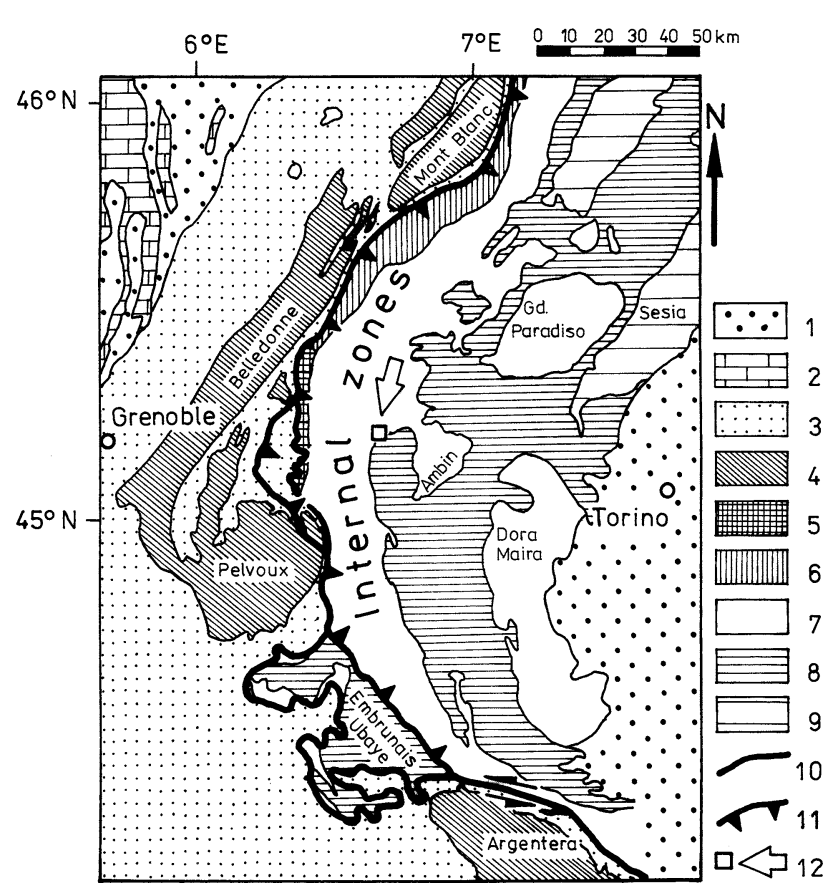

Fig. 1 Simplified geological overview of the Western Alps after [10, $13,15,26]$ showing the location of the study area. 1 Molase basin (undifferentiated); 2 Jura belt (undifferentiated), Dauphinois Domain; 3 Triassic/Jurassic; 4 Basement (external massifs), Penninic Domain; 5 Cheval Noir unit; 6 North Penninic (Valaisan); 7 Middle Penninic (Briançonnais/Subbriançonnais); 8 South Penninic (Piemont-Liguria); 9 Austro-/Southalpine Domain (undifferentiated); 10 Penninic Basal Contact; 11 Roselend Thrust; 12 location of the study area

Triassic to the Paleocene (having very thick Triassic layers, compared to the remaining quite thin ones), and a thick overlaying series of calcschists (schistes lustre) with intercalations of the basic rocks (greenschists). Above Aussois and the "Monolithe" outcrop, the Dent Parah formed from dark Liassic shales and phyllites from other exotic series, blocks of which may have fallen into the slope.
Location of sampling points

Samples of calcschist (no. 1, Table 1), carbonaceous breccia (no. 2), limestone dolomite (no. 3), and dolomite (no. 4) were taken from the large rock exposure locally named the "Monolithe", located at the holiday resort Aussois (Fig. 2a). Samples of marble (no. 5, Table 1) and quartzite (no. 6) were collected along the road in ModaneAussois (Fig. 2b). All of the samples were carefully separated from their rock material, and had high purity without any superficial covers.

Sample 1 is represented by grey calcschists that are very similar to calcite phyllite. The sample contains firmly tectonized thin layers of calcite and clay minerals. Due to tectonic movements, their surfaces can have a characteristic glittering, which might cause these rocks to be classified as schistes lustres [16].

Sample 2 shows the Upper Triassic carbonaceous breccia, which contains free variation forms of calcites, dolomites, quartz veins, and mainly gypsum evaporates. These rocks appear in many tectonic contacts.

Sample 3 is a Middle Triassic light grey limestone dolomite, mainly composed of dolomite with minor amounts of calcite and other clay minerals. The thin calcite veins cross dolomite in some sections. Although barely visible, the rock shows a coarse schist structure.

Sample 4 represents light grey (Middle Triassic) massive dolomites. The finely grained structure and lack of schist formation are characteristics of this rock.

Sample 5 is a Middle Triassic light grey massive marble, mainly calcite. The rock is strongly tectonized with a finely grained structure. It contains numerous examples of mutual differently-orientated mesofault surfaces, with distinctly visible tectonic striate and steps (associated with slickensides).

Sample 6 is a typical, strongly tectonized Lower Triassic thick-bedded massive quartz, and includes a slight
Table 1 Locations of the samples

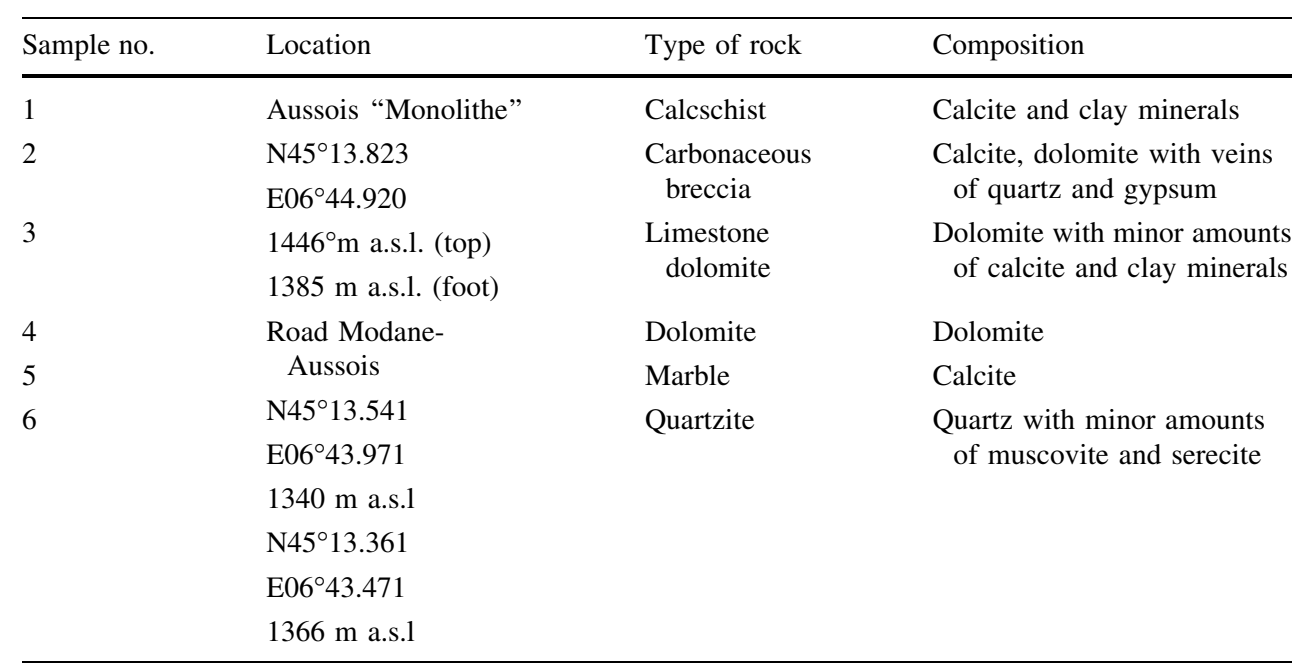


occurrence of muscovite and sericite schists, some quartzite schists, and numerous tectonic slickensides with tectoglyphs.

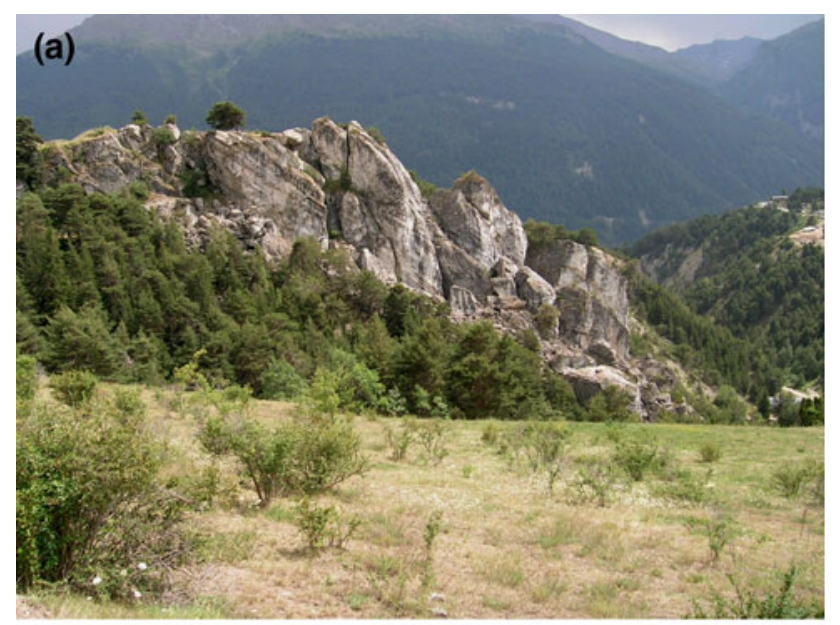

(b)



Fig. 2 Location of samples: a outcrop "Monolithe"; b road ModaneAussois

\section{Materials and methods}

The rock samples, both after crushing and 6 months after collection, were measured in a Marinelli 450 using a gammaray GX3020 (Canberra Industries) spectrometry system. The system is based on a coaxial HPGe Extended Range detector, with $32 \%$ relative efficiency, energy resolutions of $0.86 \mathrm{keV}$ at $122 \mathrm{keV}$ and $1.76 \mathrm{keV}$ at $1332 \mathrm{keV}$, and a detector bias voltage of $4000 \mathrm{~V}$. The LabSOCS (Laboratory Sourceless Calibration Software) and Genie 2000 v.3 software packages were used for the efficiency calibration and the determination of radionuclides and their activities. The energy calibration of the spectrometer was performed using homogeneously dispersed ${ }^{241} \mathrm{Am},{ }^{109} \mathrm{Cd},{ }^{139} \mathrm{Ce},{ }^{57} \mathrm{Co},{ }^{60} \mathrm{Co},{ }^{137} \mathrm{Cs},{ }^{113} \mathrm{Sn},{ }^{85} \mathrm{Sr}$, ${ }^{88} \mathrm{Y}$, and ${ }^{203} \mathrm{Hg}$ radioisotopes in silicone resin (certificate source type MBSS2). The activities of the examined radionuclides were calculated from the following gamma transitions (energy in $\mathrm{keV}):{ }^{40} \mathrm{~K}(1460.8),{ }^{208} \mathrm{Tl}(277.4,510.8,583.1$, 860.6, and 2614.5), ${ }^{212} \mathrm{~Pb}$ (238.6 and 300.0), ${ }^{214} \mathrm{~Pb}(241.9$, 295.2, and 351.9), ${ }^{214} \mathrm{Bi}(609.3,768.3,1120.3,1764.5$, and 2204.2), ${ }^{226} \mathrm{Ra}(186.2)$, and ${ }^{228} \mathrm{Ac}(338.3,911.6,964.6$, and 969.1). The total duration of a single measurement was $72 \mathrm{~h}$.

\section{Results and discussion}

The results of the gamma-ray activities of the ${ }^{40} \mathrm{~K},{ }^{208} \mathrm{Tl}$, ${ }^{212} \mathrm{~Pb},{ }^{214} \mathrm{~Pb},{ }^{214} \mathrm{Bi},{ }^{226} \mathrm{Ra}$, and ${ }^{228} \mathrm{Ac}$ samples are provided in Table 2. The gamma-ray spectra are shown in Fig. 3.

${ }^{40} \mathrm{~K}$

The highest ${ }^{40} \mathrm{~K}$ activity concentrations occurred in sample 6 (quartzite) at $572 \mathrm{Bqkg}^{-1}$, and sample 1 (calcschist) at

Table 2 Activity concentrations of primordial radionuclides in the examined samples

\begin{tabular}{|c|c|c|c|c|c|c|c|}
\hline & \multicolumn{7}{|c|}{ Activity $\mathrm{Bqkg}^{-1}$} \\
\hline & \multirow[t]{2}{*}{ Nuclide } & \multicolumn{6}{|l|}{ Sample no. } \\
\hline & & $\begin{array}{l}1 \\
\text { Calcschist }\end{array}$ & $\begin{array}{l}2 \\
\text { Carbonaceous breccia }\end{array}$ & $\begin{array}{l}3 \\
\text { Limestone dolomite }\end{array}$ & $\begin{array}{l}4 \\
\text { Dolomite }\end{array}$ & $\begin{array}{l}5 \\
\text { Marble }\end{array}$ & $\begin{array}{l}6 \\
\text { Quartzite }\end{array}$ \\
\hline \multirow{4}{*}{$\begin{array}{l}\text { Non series } \\
{ }^{232} \mathrm{Th} \text { series }\end{array}$} & ${ }^{40} \mathrm{~K}$ & $392(8)$ & $111(2)$ & $18(1)$ & $129(3)$ & $78(2)$ & $572(11)$ \\
\hline & ${ }^{208} \mathrm{Tl}$ & $6.1(1)$ & $1.7(1)$ & $0.25(5)$ & $1.3(1)$ & $0.7(1)$ & $3.4(1)$ \\
\hline & ${ }^{212} \mathrm{~Pb}$ & $19.1(3)$ & $5.6(2)$ & $0.64(9)$ & $3.9(1)$ & $2.1(1)$ & 11.1(3) \\
\hline & ${ }^{228} \mathrm{Ac}$ & $18.0(2)$ & $5.5(1)$ & $0.67(8)$ & $3.8(1)$ & $2.4(1)$ & $10.4(2)$ \\
\hline \multirow[t]{4}{*}{${ }^{238} \mathrm{U}$ series } & ${ }^{214} \mathrm{~Pb}$ & $14.8(2)$ & $22.9(2)$ & $26.9(3)$ & $29.8(3)$ & $26.1(3)$ & $9.4(2)$ \\
\hline & ${ }^{214} \mathrm{Bi}$ & $14.0(4)$ & 22.1(4) & $25.5(5)$ & $28.2(5)$ & $25.4(3)$ & $8.9(3)$ \\
\hline & ${ }^{226} \mathrm{Ra}^{\mathrm{a}}$ & $14.4(5)$ & $22.5(5)$ & $26.2(6)$ & $29.0(6)$ & $25.7(4)$ & $9.1(4)$ \\
\hline & ${ }^{226} \mathrm{Ra}^{\mathrm{b}}$ & $15.1(17)$ & $23.1(20)$ & $24.2(25)$ & $27.4(23)$ & $23.7(25)$ & $9.5(16)$ \\
\hline
\end{tabular}

Uncertainties are quoted as $1 \sigma$

${ }^{a}$ Based on ${ }^{214} \mathrm{~Pb}$ and ${ }^{214} \mathrm{Bi}$ activities. Uncertainties were calculated as: $\Delta^{226} \mathrm{Ra}=\left(\left(\Delta^{214} \mathrm{~Pb}\right)^{2}+\left(\Delta^{214} \mathrm{Bi}\right)^{2}\right)^{1 / 2}$

b Activity directly from the line $186.2 \mathrm{keV}$ 

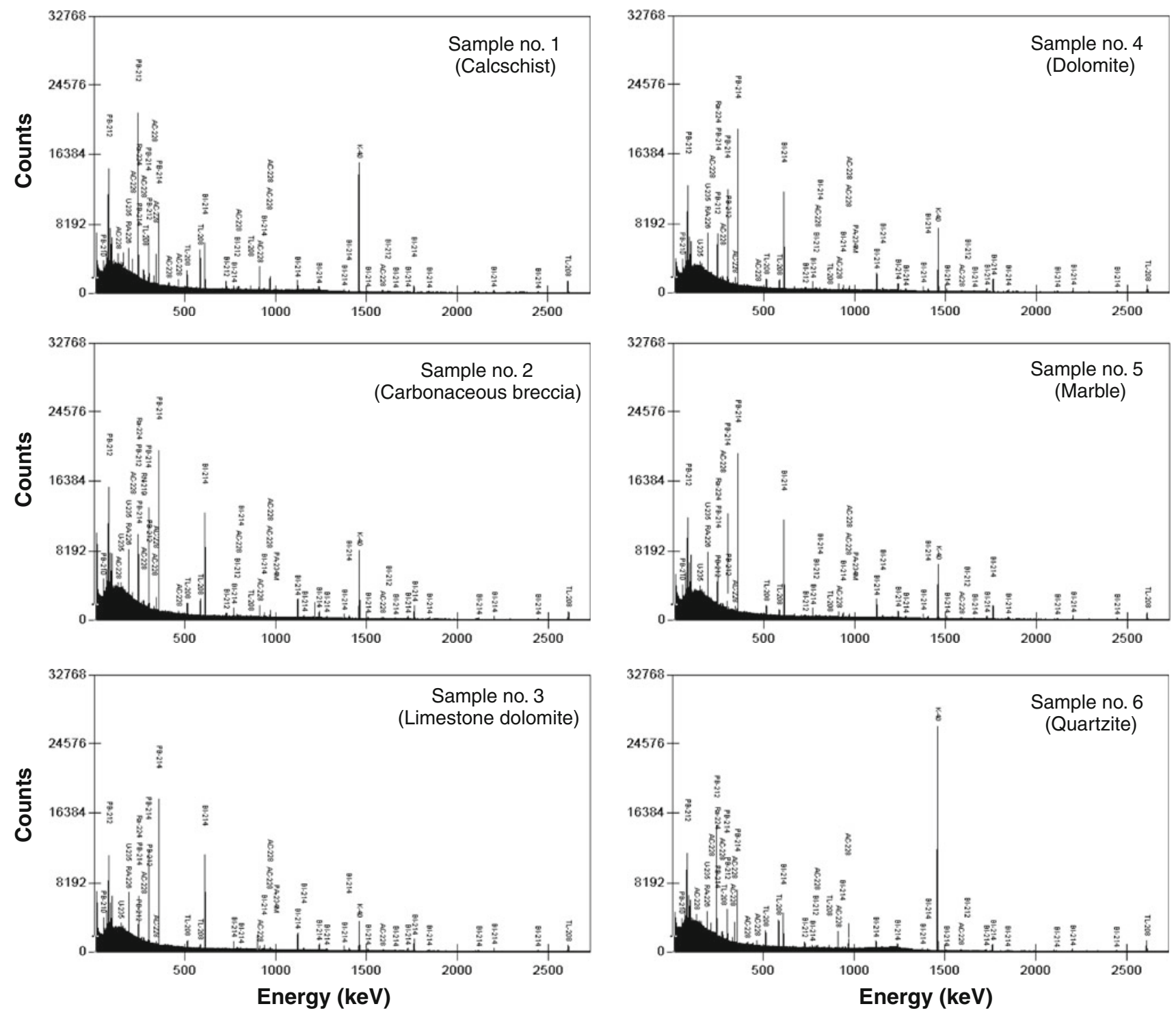

Fig. 3 Gamma-ray spectra for all the samples. The characteristic gamma-ray emitters are marked above the corresponding peaks

$392 \mathrm{Bqkg}^{-1}$ (Table 2, Fig. 4). The lowest activities occurred in samples 3 (limestone dolomite) and 5 (marble), at 18 and $78 \mathrm{Bqkg}^{-1}$, respectively. Intermediate values were observed in sample 2 (carbonaceous breccia) at $111 \mathrm{Bqkg}^{-1}$, and in sample 5 (dolomite) at $129 \mathrm{Bqkg}^{-1}$. As shown in Fig. 4, an average value of ${ }^{40} \mathrm{~K}$ activity over all samples is $217 \mathrm{Bqkg}^{-1}$. This value is relatively high compared to the average in typical carbonate rocks, $70 \mathrm{Bqkg}^{-1}$. The higher value results from increased activity concentrations of potassium-40 in calcschist and quartzite. However, the average activity calculated only from samples $2,3,4$, and 5 ("pure carbonates"), $84 \mathrm{Bqkg}^{-1}$, is close to that observed in typical carbonate rocks (Fig. 4). It should be emphasized that the ${ }^{40} \mathrm{~K}$ activity concentrations in the samples, with the exception of quartzite, are below the average activity of ${ }^{40} \mathrm{~K}$ observed in typical soils, ca $400 \mathrm{Bqkg}^{-1}[17,18]$.
${ }^{232} \mathrm{Th}$ series $\left({ }^{228} \mathrm{Ac},{ }^{212} \mathrm{~Pb},{ }^{208} \mathrm{Tl}\right)$

As seen in Table 2, radioactive equilibrium is achieved for each sample between progenies in the ${ }^{232} \mathrm{Th}$ series. Since ${ }^{228} \mathrm{Ac}$ is the second radionuclide in the thorium series, the activity concentration of ${ }^{232}$ Th can be assumed to be equal to the ${ }^{228}$ Ac activity. As seen in Fig. 5, the measured activities associated with the ${ }^{232} \mathrm{Th}$ series were the highest in calcschist (18 $\left.\mathrm{Bqkg}^{-1}\right)$ and quartzite $\left(10.4 \mathrm{Bqkg}^{-1}\right)$. By far, the lowest ${ }^{232} \mathrm{Th}$ activity below $1 \mathrm{Bqkg}^{-1}$ was observed in sample 3 (limestone dolomite). Intermediate values of 2.4, 3.8, and $5.5 \mathrm{Bqkg}^{-1}$ were found in samples 5,4 , and 2 , respectively (Table 2). The ${ }^{232}$ Th activity averaged over all the samples is $7 \mathrm{Bqkg}^{-1}$ (Fig. 5). Considering activities from the "pure carbonates" (samples 2, 3, 4, and 5), the resulting average value of $3 \mathrm{Bqkg}^{-1}$ is nearly three times lower than the 


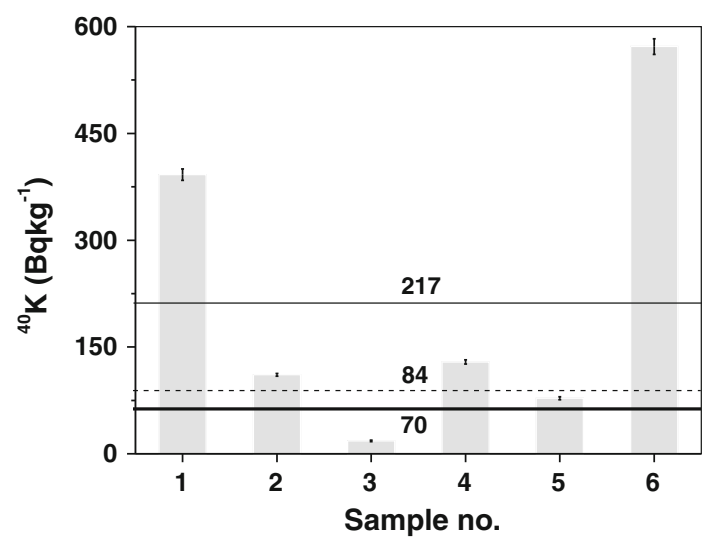

Fig. 4 Activity concentrations of ${ }^{40} \mathrm{~K}$. Thick solid line average ${ }^{40} \mathrm{~K}$ activity in typical carbonates; thin solid line average ${ }^{40} \mathrm{~K}$ activity using all the samples; thin dotted line $=$ average activity of ${ }^{40} \mathrm{~K}$ using only samples $2,3,4$, and 5

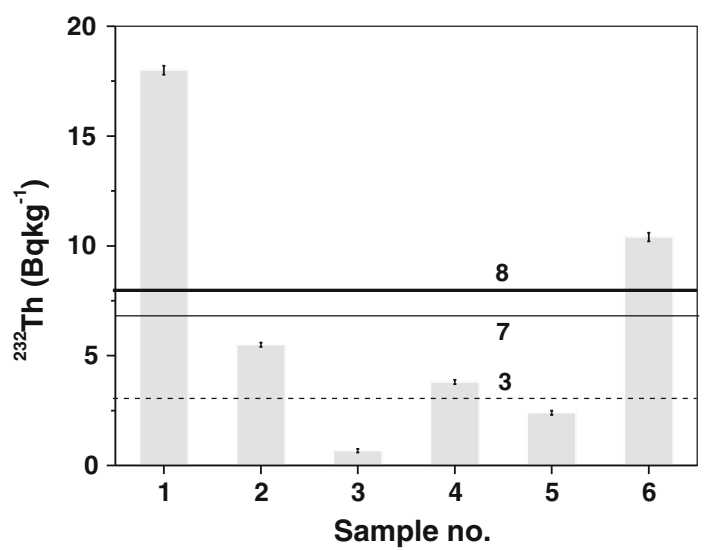

Fig. 5 Activity concentrations of ${ }^{232}$ Th. Thick solid line average ${ }^{232} \mathrm{Th}$ activity in typical carbonates; thin solid line average ${ }^{232} \mathrm{Th}$ activity using all the samples; thin dotted line average activity of ${ }^{232}$ Th using only samples $2,3,4$, and 5



Fig. 6 Activity concentrations of ${ }^{238} \mathrm{U}$. Thick solid line average ${ }^{238} \mathrm{U}$ activity in typical carbonates; thin solid line average ${ }^{238} \mathrm{U}$ activity using all the samples; thin dotted line average activity of ${ }^{238} \mathrm{U}$ using only samples 2, 3, 4, and 5 average reported for carbonates, $8 \mathrm{Bqkg}^{-1}$ [17]. Similar to the results for ${ }^{40} \mathrm{~K}$, the average activity of ${ }^{232} \mathrm{Th}$ in the investigated rocks is clearly below the averages of ${ }^{232} \mathrm{Th}$ observed in a typical soil $\left(37 \mathrm{Bqkg}^{-1}\right)$ and in the continental crust (44 $\mathrm{Bqkg}^{-1}$ ).

${ }^{238} \mathrm{U}$ series $\left({ }^{214} \mathrm{~Pb},{ }^{214} \mathrm{Bi},{ }^{226} \mathrm{Ra}\right)$

Activity concentrations of ${ }^{238} \mathrm{U}$ were estimated assuming radioactive equilibrium in the ${ }^{238} \mathrm{U} \rightarrow{ }^{226} \mathrm{Ra} \rightarrow{ }^{222} \mathrm{Rn} \rightarrow$ ${ }^{214} \mathrm{~Pb} \rightarrow{ }^{214} \mathrm{Bi}$ decay chain (occurring in the vast majority of minerals and rocks) [19]. As shown in Table 2, the mean values of the ${ }^{226} \mathrm{Ra}$ activity calculated from ${ }^{214} \mathrm{~Pb}$ and ${ }^{214} \mathrm{Bi}$ correspond to the values obtained directly from line $186.2 \mathrm{keV}\left({ }^{226} \mathrm{Ra}\right)$. Due to a strong overlap between the line $186.2 \mathrm{keV}$ and the line $185.7 \mathrm{keV}\left({ }^{235} \mathrm{U}\right)$, and the relatively high background in this energy range, the corresponding cumulative uncertainties are naturally higher than those calculated from the averaged values for ${ }^{214} \mathrm{~Pb}$ and ${ }^{214} \mathrm{Bi}$. Therefore, in our work, the ${ }^{226} \mathrm{Ra}\left({ }^{238} \mathrm{U}\right)$ estimate was determined from ${ }^{214} \mathrm{~Pb}$ and ${ }^{214} \mathrm{Bi}$ activities.

Table 2 shows the highest activity concentrations of ${ }^{238} \mathrm{U}$ in dolomite $\left(29 \mathrm{Bqkg}^{-1}\right)$, with the next highest in limestone dolomite and marble (ca $26 \mathrm{Bqkg}^{-1}$ in both). Unlike with ${ }^{40} \mathrm{~K}$ and ${ }^{232} \mathrm{Th}$, the lowest activity concentrations of ${ }^{238} \mathrm{U}$ were observed in quartzite $\left(9.5 \mathrm{Bqkg}^{-1}\right)$ and calcschist (14.4 $\mathrm{Bqkg}^{-1}$; Table 2 and Fig. 6). An intermediate value was observed in carbonaceous breccia (22.5 $\left.\mathrm{Bqkg}^{-1}\right)$. As seen in Fig. 5, an average value of ${ }^{238} \mathrm{U}$ for all investigated rocks is $21 \mathrm{Bqkg}^{-1}$. An average using just samples $2,3,4$, and 5 is $26 \mathrm{Bqkg}^{-1}$; this value is the same as the average reported for typical carbonate rocks $\left(25 \mathrm{Bqkg}^{-1}\right)$, within measurement uncertainty.

Concentrations of $\mathrm{K}(\%),{ }^{232} \mathrm{Th}(\mathrm{ppm})$, and ${ }^{238} \mathrm{U}$ (ppm)

The concentrations of $\mathrm{K}(\%),{ }^{232} \mathrm{Th}(\mathrm{ppm})$, and ${ }^{238} \mathrm{U}(\mathrm{ppm})$ were calculated from the activity concentrations of ${ }^{40} \mathrm{~K}$, ${ }^{228} \mathrm{Ac}$, and ${ }^{226} \mathrm{Ra}$ (Table 3). Also seen in Table 3, the highest concentrations of $\mathrm{K}$ were found in quartzite $(1.89 \%)$ and calcschist (1.29\%). An exceptionally low concentration, $0.06 \%$, was calculated for limestone dolomite. The average concentration of $\mathrm{K}$ in the investigated rocks was $0.71 \%$.

Concentrations of ${ }^{232} \mathrm{Th}$ varied from $0.16 \mathrm{ppm}$ in limestone dolomite to $4.38 \mathrm{ppm}$ in calcschist. The concentration of ${ }^{232} \mathrm{Th}$ averaged over all the samples is $1.65 \mathrm{ppm}$. Concentrations of ${ }^{238} \mathrm{U}$ for samples $2,3,4$, and 5 vary within a narrow range from $1.8 \mathrm{ppm}$ (carbonaceous breccia) to $2.3 \mathrm{ppm}$ (dolomite). Similar to the activity levels, the lowest concentrations of ${ }^{238} \mathrm{U}$ were obtained in quartzite $(0.73 \mathrm{ppm})$ and calcschist (1.2 ppm; Table 3$)$. The average concentration of ${ }^{238} \mathrm{U}$ is $1.7 \mathrm{ppm}$. 
Table 3 Concentrations of K (\%), ${ }^{232} \mathrm{Th}(\mathrm{ppm})$, and ${ }^{238} \mathrm{U}(\mathrm{ppm})$

\begin{tabular}{|c|c|c|c|c|c|c|}
\hline \multirow[t]{2}{*}{ Nuclide } & \multicolumn{6}{|l|}{ Sample no. } \\
\hline & $\begin{array}{l}1 \\
\text { Calcschist }\end{array}$ & $\begin{array}{l}2 \\
\text { Carbonaceous breccia }\end{array}$ & $\begin{array}{l}3 \\
\text { Limestone dolomite }\end{array}$ & $\begin{array}{l}4 \\
\text { Dolomite }\end{array}$ & $\begin{array}{l}5 \\
\text { Marble }\end{array}$ & $\begin{array}{l}6 \\
\text { Quartzite }\end{array}$ \\
\hline $\mathrm{K}(\%)$ & $1.29(3)$ & $0.37(1)$ & $0.059(3)$ & $0.43(1)$ & $0.26(1)$ & $1.89(4)$ \\
\hline${ }^{232} \mathrm{Th}(\mathrm{ppm})$ & $4.38(5)$ & $1.34(2)$ & $0.16(2)$ & $0.92(2)$ & $0.58(2)$ & $2.53(5)$ \\
\hline${ }^{238} \mathrm{U}(\mathrm{ppm})$ & $1.16(4)$ & $1.81(4)$ & $2.11(5)$ & $2.33(5)$ & $2.07(3)$ & $0.73(3)$ \\
\hline
\end{tabular}

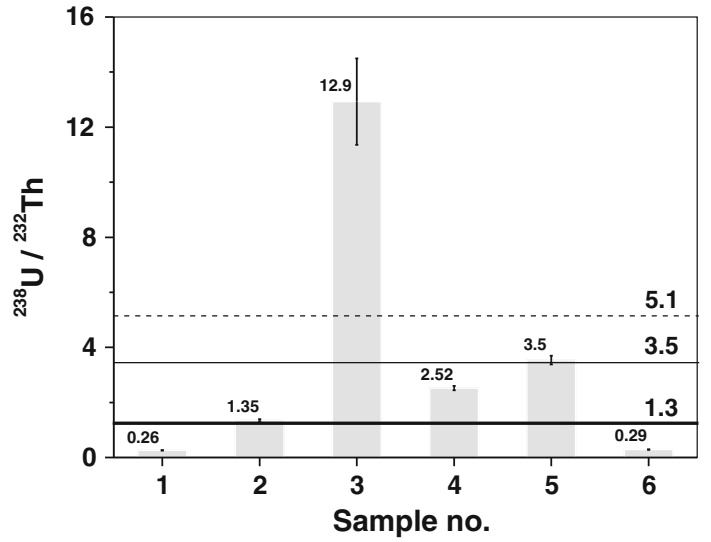

Fig. 7 Concentration ratios of ${ }^{238} \mathrm{U} /{ }^{232} \mathrm{Th}$. Thick solid line average reported for the ${ }^{238} \mathrm{U} /{ }^{232} \mathrm{Th}$ ratio in typical carbonates; thin solid line average ${ }^{238} \mathrm{U} /{ }^{232} \mathrm{Th}$ ratio using all the samples; thin dotted line average ${ }^{238} \mathrm{U} /{ }^{232} \mathrm{Th}$ ratio using only samples $2,3,4$, and 5
The concentration ratios of ${ }^{238} \mathrm{U} /{ }^{232} \mathrm{Th}$ in the investigated rocks are shown in Fig. 7. These ratios ranged from 0.26 in calcschist to 12.9 in limestone dolomite. The ratio averaged over all the samples is 3.5 , while the average just from samples 2, 3, 4, and 5 is 5.1. Both of these values are noticeable higher than the average ratio in typical carbonates, i.e., 1.3 [20].

Values higher than these presented here for "pure limestone", samples 2, 3, 4 and 5, were measured in limestone rocks in northern Iraq [21]. The activity concentrations of ${ }^{40} \mathrm{~K}$ and ${ }^{238} \mathrm{U}$ in these rocks changed from 28 to 64 and 290 to $637 \mathrm{Bqkg}^{-1}$, respectively.

Comparable values to marble from Aussois, sample 5, have been reported for marbles available in the Rawalpindi/ Islamabad area [22]. The measured activities of ${ }^{40} \mathrm{~K},{ }^{232} \mathrm{Th}$ and ${ }^{238} \mathrm{U}$ varied in the range of $6-159,1.2-6.3$ and $1.4-29 \mathrm{Bqkg}^{-1}$, respectively. Similar activity of ${ }^{238} \mathrm{U}$, $33 \mathrm{Bqkg}^{-1}$, was found in marble from Italy [23], whereas
Fig. 8 Correlations between: a ${ }^{232} \mathrm{Th}(\mathrm{ppm})$ vs. ${ }^{40} \mathrm{~K}(\%)$; b ${ }^{238} \mathrm{U}(\mathrm{ppm})$ vs. ${ }^{40} \mathrm{~K}(\%)$; and c ${ }^{232} \mathrm{Th}$ (ppm) vs. ${ }^{238} \mathrm{U}$ (ppm). The solid lines represent linear fits: ${ }^{232} \mathrm{Th}(\mathrm{ppm})=1.72 \times{ }^{40} \mathrm{~K}$ $(\%)+0.42 ;{ }^{238} \mathrm{U}(\mathrm{ppm})$ $=-0.83 \times{ }^{40} \mathrm{~K}(\%)+2.29$; and ${ }^{232} \mathrm{Th}(\mathrm{ppm})=$

$-1.97 \times{ }^{238} \mathrm{U}(\mathrm{ppm})+4.99$. The correlation coefficients are $R=0.78,-0.94$, and -0.78 , respectively

activity concentrations of ${ }^{40} \mathrm{~K}\left(<1 \mathrm{Bqkg}^{-1}\right)$ and ${ }^{232} \mathrm{Th}$ $\left(0.4 \mathrm{Bqkq}^{-1}\right)$ in the same rock were noticeably lower.

Activities similar to these observed in sample 6 (quartzite) have been recorded in quartzite presented in paper [24]. Significantly higher activity concentrations of primordial radionuclides have been measured in quartzite from India [25]. The average activity concentrations of ${ }^{40} \mathrm{~K},{ }^{232} \mathrm{Th}$ and ${ }^{238} \mathrm{U}$ in these rocks were 741,48 and $112 \mathrm{Bqkg}^{-1}$, respectively.

Intercolerrations of $\mathrm{K}(\%),{ }^{232} \mathrm{Th}(\mathrm{ppm})$, and ${ }^{238} \mathrm{U}(\mathrm{ppm})$

Figure 8 shows distinct intercolerrations between the K, ${ }^{232} \mathrm{Th}$, and ${ }^{238} \mathrm{U}$ concentrations in the investigated rocks. A positive correlation is seen between ${ }^{232} \mathrm{Th}$ and $\mathrm{K}$ (Fig. 8a). Even though points 1 and 6 (representing calcschist and quartzite) show noticeable deviations from the fitted line, the correlation coefficient is relatively high, $R=0.78$. A strong negative correlation is clearly visible between the ${ }^{238} \mathrm{U}$ and $\mathrm{K}$ concentrations (Fig. 8b), with a correlation coefficient $R=-0.94$. Only point 4 , representing dolomite, shows a slight deviation from a linear fit. As may be expected, a negative correlation is also observed between ${ }^{232} \mathrm{Th}$ and ${ }^{238} \mathrm{U}$, with $R=-0.78$ (Fig. 8c). Similar to the ${ }^{232} \mathrm{Th}-\mathrm{K}$ dependence, there are noticeable deviations from the fitted line for calcschist (point 1) and quartzite (point 6).

\section{Conclusions}

Characteristic rocks of the Modane-Aussois region showed relatively low activity concentrations of ${ }^{40} \mathrm{~K},{ }^{232} \mathrm{Th}$, and ${ }^{238} \mathrm{U}$. The highest activities for ${ }^{40} \mathrm{~K}$ and ${ }^{232} \mathrm{Th}$ were measured in quartzite and calcschist $\left(572 \mathrm{Bqkg}^{-1}\right.$ and $18 \mathrm{Bqkg}^{-1}$, respectively). The highest activity of ${ }^{238} \mathrm{U}$ $\left(29 \mathrm{Bqkg}^{-1}\right)$ was noted in dolomite. The concentration ratios of ${ }^{238} \mathrm{U} /{ }^{232} \mathrm{Th}$ in the investigated rocks varied from 0.26 in calcschist to 12.9 in limestone dolomite, with an average value of 3.5. A positive correlation was noted between the ${ }^{40} \mathrm{~K}$ and ${ }^{232} \mathrm{Th}$ concentrations, whereas correlations between ${ }^{40} \mathrm{~K}$ and ${ }^{238} \mathrm{U}$ and between ${ }^{238} \mathrm{U}$ and ${ }^{232} \mathrm{Th}$ were noticeably negative.

Open Access This article is distributed under the terms of the Creative Commons Attribution Noncommercial License which permits any noncommercial use, distribution, and reproduction in any medium, provided the original author(s) and source are credited.

\section{References}

1. Merle O, Brun JP (1984) The curvedtranslation path of the Parpaillon Nappe (French Alps). J Struct Geol 6(6):711-719
2. Mugnier JL, Loubat H, Cannic S (1993) Correlation of seismic images and geology at the boundary between internal and external domains of the Western Alps. Bull de la Société Géologique de France 164:697-708

3. Mosar J, Stampfli GM, Girod F (1996) Western Prealpes Medianes Romandes: timing and structure; a review. Eclog Geol Helv 89(1):389-425

4. Bagnoud A, Wernli R, Sartori M (1998) Decouverte de foraminiferes planctoniques paleogenes dans la zone de SionCourmayeur a Sion (Valais, Suisse). Eclog Geol Helv 91(3): 421-429

5. Butler RWH (1992) Thrust zone kinematics in a basement-cover imbricate stack: eastern Pelvoux Massif, French Alps. J Struct Geol 14:29-40

6. Spencer S (1992) A kinematc analysis incorporating incremental strain data for the frontal Pennine zones of the western French Alps. Tectonophysics 206(3-4):285-305

7. Seward D, Mancktelow NS (1994) Neogene kinematics of the Central and Werstern Alps: evidence from fission-track dating. Geology 22(9):803-806

8. Bürgisser J, Ford M (1998) Overthrust shear deformation of a foreland basin: structural studies south-east of the Pelvoux Massif, SE France. J Struct Geol 20(11):1455-1475

9. Schmid SM, Kissling E (2000) The arc of the Western Alps in the light of geophysical data on deep crustal structure. Tectonics 19:62-85

10. Fügenschuh B, Schmid SM (2003) Late stages of deformation and exhumation of an orogen constrained by fission-track data: a case study in the Western Alps. Geol Soc Am Bull 115(11):1425-1440

11. Ceriani S, Schmid SM (2004) From N-S collision to WNWdirected post-collisional thrusting and folding: structural study of the Frontal Penninic Units in Savoie (Western Alps, France). Eclog Geol Helv 97:347-369

12. Ford M, Duchêne S, Gasquet D, Vanderhaeghe O (2006) Twophase orogenie convergence in the external and internal SW Alps. J Geol Soc London 163:1-12

13. Ceriani S, Fügenschuh B, Schmid SM (2001) Multi-stage thrusting at the "Penninic front" in the Western Alps between Mont Blanc and Pelvoux massifs. Int J Earth Sci 90:685-702

14. Tricart $P$ (2004) From extension to transpression during the final exhumation of the Pelvoux and Argentera massifs, Western Alps. Eclog Geol Helv 97:429-439

15. Trullenque G, Kunze K, Heilbronner R, Stünitz H, Schmid SM (2006) Microfabrics of calcite ultramylonites as records of coaxial and non-coaxial deformation kinematics: examples from the Rocher de l'Yret shear zone (Western Alps). Techtonophysics 424:69-97

16. Tricart P, Schwartz S (2006) A north-south section across the Queyras Schistes lustrés (Piedmont zone, Western Alps): syn-collision refolding of a subduction wedge. Eclog Geol Helv 99:429-442

17. Eisenbud M, Gesell T (1997) Environmental radioactivity from natural, industrial, and military sources. Academic Press, San Diego, pp 134-200

18. Malczewski D, Teper L, Dorda J (2004) Assessment of natural and anthropogenic radiaoctivity levels in rocks and soils in the environs of Swieradow Zdroj in Sudetes, Poland, by in situ gamma-ray spectrometry. J Environ Radioact 73(3):233-245

19. Attendorn HG, Bowen RNC (1997) Radioactive and stable isotope geology. Chapman \& Hall, London

20. Van Schmus WR (1995) Natural radioactivity of the crust and mantle. In: Ahrens TJ (ed) Global earth physics. American Geophysical Union, Washington, pp 283-291

21. Najam LA, Al-Jomaily FM, Al-Farha EM (2011) Natural radioactivity levels of limestone rocks in northern Iraq using gamma spectroscopy and nuclear track detector. J Radioanal Nucl Chem 289:709-715 
22. Aslam M, Orfi SD, Khan K, Jabbar A (2002) Radiological significance of Pakistani marble used for construction of dwellings. J Radioanal Nucl Chem 253:483-487

23. Hassan NM, Ishikawa T, Hosoda M, Sorimachi A, Tokonami S, Fukushi M, Sahoo SK (2010) Assessment of the natural radioactivity using two techniques for the measurement of radionuclide concentration in building materials used in Japan. J Radioanal Nucl Chem 283:15-21

24. Yeboah J, Boadu M, Darko EO (2001) Natural radioactivity in soils and rocks within the Greater Accra Region of Ghana. J Radioanal Nucl Chem 249:629-632
25. Banerjee KS, Guin R, Gutierrez-Villanueva JL, Charro ME, Sengupta D (2011) Variation in U-238 and Th-232 enrichment in U-mineralized zone and geological controls on their spatial distribution, Singhbhum Shear Zone of India. Environ Earth Sci doi: 10.1007/s12665-011-1191-9

26. Dumont T, Champagnac JD, Crouzet C, Rochat P (2008) Multistage shortening in the Dauphiné zone (French Alps): the record of Alpine collision and implications for pre-Alpine restoration. Swiss J Geosci 101:89-100 